\title{
The relationship between personality, organizational and interpersonal counterproductive work challenges in industry 4.0
}

\author{
Dawid SZOSTEK ${ }^{1}$, Adam P. BALCERZAK ${ }^{2} *$ and Elïbieta ROGALSKA ${ }^{3}$
}

\begin{abstract}
Authors' affiliations and addresses:
Nicolaus Copernicus University in Torun

Poland, Faculty of Economic Sciences and Management, ul. Gagarina 13, 97-100 Toruń,

Poland

e-mail: dawid.szostek@umk.pl
\end{abstract}

${ }^{2}$ University of Warmia and Mazury in Olsztyn, Poland, University of Entrepreneurship and Law, Czech Republic

Brno University of Technology, Czech Republic Faculty Economic Sciences, Department Market and Consumption, pl. Cieszyński 1/327, 10-720

Olsztyn, Poland

e-mail: a.balcerzak@uwm.edu.pl

${ }^{3}$ University of Warmia and Mazury in Olsztyn, Poland, Faculty Economic Sciences, Department of Theory of Economics, ul. R. Prawocheńskiego 19/205 10-720 Olsztyn, Poland

e-mail: elzbieta.rogalska@uwm.edu.pl

*Correspondence:

Adam P. Balcerzak, Faculty Economic Sciences, Department Market and Consumption, pl. Cieszyński 1/327, 10-720 Olsztyn, Poland e-mail: a.balcerzak@uwm.edu.pl

Acknowledgment:

The project was funded by the National Science Centre, Poland, on Decision No. 2019/03/X/HS4/00350.

How to cite this article:

Szostek, D., Balcerzak, A., P., and Rogalska, E. (2020). The relationship between personality, organizational and interpersonal

counterproductive work challenges in industry 4.0. Acta Montanistica Slovaca, Volume 25 (4), 577-592

DOI:

https://doi.org/10.46544/AMS.v25i4.11

\begin{abstract}
The current study is related to the empirical gap on the relation between personality traits and counterproductive behavior, which is especially important for literature concerning Central and Eastern post-transformation economies. Therefore, the main empirical goal of the article is to determine how the personality traits (Extraversion, Neuroticism, Conscientiousness, Agreeableness, and Openness to experience) influence the extent of organizational and interpersonal counterproductive work behaviors (CWB; CWB-O; CWB-I) and how this relation is moderated by the demographic and professional characteristics of employees (sex, age, seniority or type of work). The research objectives were met using a survey conducted in April 2020 among 454 professionally active people in Poland. Structural equation modeling (SEM) was applied to analyze the empirical data. The proposed theoretical model was intended to determine how particular types of personality impact CWB. Based on the empirical results, we determined that personality traits strongly affect counterproductive work behaviors. The strongest predictors of organizational CWB proved to be Conscientiousness (negative relation) and Agreeableness (positive relation). There was no direct effect of personality traits on CWB-I. Moreover, the relationship between personality traits and CWB-O/I was significantly moderated by the demographic and professional characteristics of employees (sex, age, seniority, or type of work). The discussed result is reached based only on Polish employees' sample, which can be considered its important limitation. However, it still contributes significantly to international behavioral economics literature in the field. Due to many institutional characteristics and similar social context, the conclusions can be generalized and attributed at least for other Central European economies which are at the same level of development and which are characterized by many social and cultural similarities. From the practical perspective, the obtained results can be of special importance for human resource management in the reality of Industry 4.0 challenges.
\end{abstract}

\section{Keywords}

personality traits; counterproductive work behaviors, behavioral economics, Structural Equation Modeling (SEM), Polish employees 


\section{Introduction}

Counterproductive behavior (CWBs) is a subject of growing interest both among behavioral economists and professional managers, mainly due to its high costs for enterprises or, wildly speaking, all kind of organizations, which at the same time must generate high social negative consequences (Mount et al., 2006). In recent years this issue has special importance from the perspective of the growing role of effective human resource management in the reality of Industrial 4.0. challenges. Considering these consequences, a variety of methods to investigate employees' behavior are used, including those based on large-scale nationwide surveys (Abdillah et al., 2018; Brycz et al., 2019). Therefore, depending on the scale of analysis and specific point of view, the discussed factor can result in decreasing international competitiveness at the micro-level or even threaten the long term sustainability of an enterprise (Vveinhardt \& Sroka, 2020; Balcerzak \& MacGregor Pelikánová, 2020; Hussain et al., 2020; Kot et al., 2020), but it can also bring negative consequences at the macro level. For example, already in the begging of the current century, U.S. businesses assessed the CWBs costs at approximately $\$ 50$ billion annually, and this factor could account for even $20 \%$ of failed businesses (Coffin, 2003). Moreover, about $95 \%$ of organizations are victims of employee's theft and fraud (Case, 2000). Besides, CWBs are responsible for higher absenteeism rates and lower turnover or productivity (Hoel et al., 2003).

Behavioral economics, and especially psychologists, argue that conditions of CWBs are complex and can be divided into situational (including organizational and non-organizational) and individual. Organizational reasons (for example, unfair remuneration, boredom at work, job dissatisfaction, lack of employee control) mainly result in behavior aimed negatively at the organization (for example, retaliation), while interpersonal reasons (for example, an argument with colleagues, low-quality relationships at work) determine behavior directed at other people (Kwok et al., 2005; Mount et al., 2006; Bechtoldt et al., 2007; Berry et al., 2007; Everton et al., 2007; Kwahar \& Iyortsuun, 2018; Pisar \& Bilkova, 2019. Szostek, 2019b; Anyakoha, 2019; Mura et al., 2019, Jędrzejczak-Gas \& Wyrwa, 2020; Bernardi, 2019; Laužikas, \& Miliūtė, 2020; Hitka et al., 2020). Within this context, one should also underline the importance of authentic leadership and the negative implications of its lack (for example, ul Haque et al., 2020; Sroka \& Vveinhardt, 2020).

Non-organizational reasons for CWB may be social (for example, national culture), economic (for example, pauperization), technological (for example, popularization of the Internet), legal and institutional (for example, loopholes in the law regarding the penalization of mobbing) (Szostek, 2019a) and environmental (for example, air pollution; Fehr et al., 2017). Therefore, they should be analyzed in a given specific context, and the results obtained for a given social environment (for example, country) cannot be easily generalized.

Individual causes of CWB mainly concern psychosomatic, demographic, and professional characteristics of employees, such as self-control, age, gender, and past history (for example, aggressive parents or previous involvement in CWB), education, seniority (Furnham \& Miller, 1997; Douglas \& Martinko, 2001; Ones et al., 2003; Ng \& Feldman, 2009; Salami, 2010; Pekerşen \& Tugay, 2020; Babikova \& Bucek, 2019). A specific factor that determines the tendency to CWBs are the personality traits of an employee (Mount et al., 2006). Some authors consider this factor crucial for the research on general CWB and specific cases of such behaviors (for example, Miller \& Lynam, 2001; Salgado, 2002). The literature emphasizes the insufficiency of studies on the direct influence of personality traits on CWB and other negative phenomena in organizations and societies (Mount et al., 2006; Marcus et al., 2007; Wroblowska, 2019). This empirical literature gap is especially visible in the case of studies concerning Central European post-transformation societies that at the same time face the process of very rapid institutional reforms, economic modernization, and abrupt social changes.

These factors mentioned above make the issue not only multidisciplinary from the theoretical perspective, but the topic is also especially interesting from the perspective of all fields of behavioral sciences, such as economics and management sciences, and the obvious very practical implications (Cismas et al., 2019). However, on the other hand, from the strictly methodological perspective and because of the need for sufficient methodological rigor, the issue is difficult to study and measure due to the multivariate and mostly latent character of the factors under evaluation (see Balcerzak, 2020).

Earlier studies on this topic, as it was already mentioned, distinguished between individual- and organizationtargeted behaviors (Robinson \& Bennett, 1995), where interpersonal CWBs are behaviors directed at other people in the organization (for example, coworkers, customers) and organizational CWBs are behaviors that harm the organization. It was also analyzed how personality traits affect selected manifestations of CWB (for example, disciplinary actions, not following directions, unauthorized absences, and drug and alcohol use on the job, property damage, workplace violence, and aggression (Hough, 1992; Schmidt et al., 1997; Douglas \& Martinko, 2001; Ones \& Viswesvaran, 2001; Salgado, 2002).

Analyzing the impact of personality on CWB-O and CWB-I and how this relationship is moderated by demographic characteristics of employees could help to better understand the personality and CWBs. Besides, it can also help to work out new practical ways for reducing CWBs. For this reason, it is so important to find the moderators which shape the relationship between personality traits and CWBs. Research on this topic is rare, and the empirical studies are still rather at an early stage of methodological development (for example, Mount et al., 
2006). Finally, based on the current knowledge of authors, no one has studied the relationship between these factors in Polish socio-cultural conditions so far. As it was already pointed out, these specific conditions are so important (Ferreira \& Nascimento, 2016) that the empirical study requires the use of validated and adapted measuring instruments to a given socio-economic context. However, it can be assumed that the research for Polish employees, despite the geographical limitation, can be generalized and attributed at least to other Central European economies that are at the same level of development and are characterized by many social and cultural similarities. Though, it must be strongly stressed that this potential generalization cannot be automatic, and all the eventual conclusions moved to the international context, even the ones close from the socio-cultural point of view, must but be done very carefully.

Summarizing the above considerations and the existing gaps in knowledge about the presented issue, the authors set the following goals for the current study:

1. determining how employees' personality traits affect counterproductive behavior at work (both in relation to CWB-I and CWB-O);

2. determining if and how the impact of employee personality traits on counterproductive behavior in relation to organizations and other people is moderated by employees' demographic and professional characteristics

(sex, age, seniority, or type of work).

These goals will be achieved using a survey conducted in April 2020 on a sample of 454 professionally active people in Poland and an application of Structural Equation Modeling (SEM) methodology. The current research, to some extent, is a continuation of previous studies conducted by Szostek (2019b), where the main attention was given to the determination of the influence of interpersonal relationships at work (QIRW) on the extent of counterproductive work behavior and its moderation by the demographic features. Therefore, in contrast to previous studies, the current research starts with the same moderating factors, but it focuses directly on the counterproductive work behaviors.

It can be expected that the current research will be the source of a significant contribution to the relevant international literature in two key areas. First, this study describes the influence of employee personality traits on counterproductive behavior at work in the Central European context with a formal modeling proposal (both with respect to CWB-I and CWB-O) reliably. What is more, this study also describes how this impact is moderated by the demographic and professional characteristics of employees (sex, age, seniority, or type of work), as these factors are crucial for overall enterprise performance (Bilan et al., 2020).

In the following sections, the literature review devoted to the theoretical framework of the research is presented, which resulted in the development of two main empirical hypotheses. Next, we apply Structural Equation Modeling (SEM) methodology, which is especially useful for research on latent factors such as the ones described in the current paper. Then, we discuss the empirical results of this study and the contributions of those findings. Lastly, we face the limitations, future research directions, and in the conclusions, we give practical implications of the current contribution.

\section{Literature review, the analytical framework, and hypotheses development}

\section{Employees' personality}

Personality is an "individual's tendency to think, feel, and act in certain consistent ways" (Miller et al., 2003, p. 497). In spite of the latent character, it has been shown that personality traits can be quite reliably, and to some extent objectively, measured and, which is the most important, the knowledge about them can be very useful in explaining human behavior (Miller et al., 2003). Similar personality traits were found across different sexes, ages, cultures, and languages (for example, Costa et al., 1991; Molose, Goldman, \& Thomas, 2018), and these traits are stable across time (Costa \& McCrae, 1988), which is crucial for building theory, which at the same time can bring important practical implications (Czerwonka, 2019).

Personality traits can help with understanding employee behavior - it is not without reason that their role is the subject of interests not only for psychologists or sociologists but on the practical side their influence on, for example, committed crimes or accidents at work are often examined (for example, Collins \& Schmidt, 1993; Heaven, 1996; Iverson \& Erwin, 1997). It is sufficient to mention that only in the U.S. are integrity tests completed by 5 million job applicants (Schmidt et al., 1997). This serves to establish to what extent job applicants or employees are willing to engage in CWB. The growing practical role of psychological tests can be seen in European countries, where these tools tend to become the key element for managerial decisions.

There are many validated models of personality and less or more reliable instruments for measuring personality traits (Miller et al., 2003). Costa \& McCrae (1990) proposed the Five-Factor Model (FFM; Big Five; OCEAN model). It is the most investigated and empirically tested model of personality (Ferreira \& Nascimento, 2016). FFM contains five domains, each comprised of six specific personality traits (Judge et al., 1997; Skarlicki et al., 1999; Mount et al., 2006): 
- Extraversion - how much the employees are sociable and talkative,

- Conscientiousness - how much the employees are dependable (dutiful, reliable, rules-compliant) and achievement-oriented (hardworking and goal-directed),

- Neuroticism - lack of emotional stability, pessimism, nervousness. Neurotic employees are more likely to engage in withdrawal. On the other hand, employees with low assessment in neuroticism scale are more optimistic and less stressed,

- Agreeableness - how much the employees are emphatic, cooperative, and trusting,

- Openness to experience - how much the employees are imaginative and familiar with the contemporary world and international environment, interested in different areas.

An alternative to FFM is the HEXACO model of personality consisting of six categories of personality (five of them resemble the content of the FFM; the new one is honesty-humility) (Marcus et al., 2007). Honestyhumility is defined from the perspective of differences in a reluctance versus a willingness to exploit other people (Lee et al., 2005b). In the literature, one can also find the seven or even nine-factor models (for example, Tellegen, 1993).

\section{Counterproductivity in behaviors at work}

Counterproductive work behaviors (CWB) can be understood as a "set of distinct acts that share the characteristics that they are volitional (as opposed to accidental or mandated) and harm or intend to harm organizations and/or organization stakeholders, such as clients, coworkers, customers, and supervisors" (Spector et al., 2006, p. 447). These behaviors are also known as deviant (Robinson \& Bennett, 1995), antisocial (Miller et al., 2003), unruliness (Hunt, 1996), destructive, hazardous (Murphy, 1993), or unethical. These concepts are not identical, but counterproductivity is a dominant term, and best captures the essence of negative/undesirable behavior at work. The behavior must meet three requirements for it to be considered counterproductive (Spector \& Fox, 2010):

1. violates the rules of the organization,

2. is volitional,

3. harms or may harm the organization and/or its stakeholders.

CWBs have a very broad spectrum of meaning, as they include both "innocent or small" cases of abuse (for example, online shopping while working) and serious violations of organizational standards and even the law (for example, theft, mobbing). There are many classifications of counterproductive behavior (see, for example, Hollinger \& Clark, 1982; Robinson \& Bennett, 1995; Gruys \& Sackett, 2003; Vardi \& Weitz, 2004), but only a few of them are exhaustive and disjointed. In practice, the classification the most frequently used is the one proposed by Spector et al. (2006). Some authors (see Robinson \& Bennett, 1995) distinguished CWB aimed against other people (CWB-I) and against the organization (CWB-O). They also proposed 5 subject categories for CWB:

1. abuse against others - behavior which is harmful to other stakeholders (for example, gossiping about someone, cheating),

2. production deviance - performing duties in a way that prevents proper completion of work (for example, breaking health and safety at work, or "Italian strike"),

3. sabotage - deliberate destruction of the organization's property (for example, devices, image),

4. theft - misappropriation of property belonging to company or other's people property,

5. withdrawal - reducing the working time below the minimum necessary to achieve the goals (for example, extending breaks, unjustified dismissals).

Abuse against others, sabotage, and theft are active forms of CWB. In turn, production deviance and withdrawal are more passive forms of such behaviors. However, it should also be remembered that some passive forms of CWB are a kind of buffer protecting against the negative impact of stressors at work. The employees engaged in production deviance or withdrawal were characterized by a lower level of emotional exhaustion (Krischer et al., 2010).

\section{Hypotheses of the research}

Based on the existing main literature in the field and the current state of the art, which was already discussed in previous sections, the two empirical hypotheses were proposed, enabling the achievement of the research's proposed objectives. The empirical verification of the hypotheses can provide an important empirical 
contribution to behavioral economics both from the theoretical perspective and empirical point of view of Central European Economies, characterized by similar institutional and cultural context, which was also already stressed. Therefore, the current hypotheses will be verified specifically in the Polish socio-cultural context.

Hypothesis 1 [H1]: Personality traits of employees have a significant influence on the counterproductive work behaviors (in relation to CWB-I and CWB-O),

Hypothesis 2 [H2]: The influence of personality traits on the CWB-O/I is moderated by the demographic and professional features of employees, such as $(\mathrm{H} 2 \mathrm{a})$ sex, $(\mathrm{H} 2 \mathrm{~b})$ age, $(\mathrm{H} 2 \mathrm{c})$ seniority, and $(\mathrm{H} 2 \mathrm{~d})$ type of work (H2e).

\section{Research methodology}

\section{Sampling Procedures and Participant Characteristics}

The survey was conducted in April 2020 using an online Internet survey. In order to analyze the obtained data, the Structural Equation Modeling (SEM) methodology was applied, which is currently an empirical approach most often applied for measuring multiple-criteria phenomena described with latent variables (see Ahmed et al., 2020; Pilelienè \& Grigaliūnaitè, 2017; Rogalska \& Kuc-Czarnecka, 2020; Stelmaszczyk, 2020; Erjavec et al., 2019). The measurement covered 454 professionally active people in Poland, and the selection of the sample was non-random (on purpose). The invitation to fill in the questionnaire was sent to:

- all municipal offices in Poland (less than 2.5 thousand),

- 100 randomly selected Public Benefit Organizations (on the list: https:/www.e-pity.pl/wykaz-opp/),

- 200 enterprises included in the ranking of 200 largest companies for 2018 of the weekly business journal

"Wprost" (http://rankingi.wprost.pl/200-najwiekszych-firm\#pelna-lista).

The characteristics of the respondents according to the main demographic variables are included in Table 1.

Tab. 1. Demographic characteristics of the studied sample

\begin{tabular}{|c|c|c|c|c|c|}
\hline \multirow{3}{*}{ Sex (no persons) } & $F$ & $75.1 \%(341)$ & \multirow{3}{*}{$\begin{array}{l}\text { Current } \\
\text { employment } \\
\text { sector }\end{array}$} & public & $54.8 \%(249)$ \\
\hline & $M$ & $24.7 \%(112)$ & & private & $44.7 \%(203)$ \\
\hline & $b / o$ & $0.2 \%(1)$ & & $b / o$ & $0.4 \%(2)$ \\
\hline \multirow{5}{*}{ Age (years) } & Mean & 42.03 & \multirow{19}{*}{$\begin{array}{l}\text { Region of Poland } \\
\text { (voivodship) }\end{array}$} & dolnoślq̨skie & $4.8 \%(22)$ \\
\hline & $M I N$ & 20 & & kujawsko-pomorskie & $10.1 \%(46)$ \\
\hline & MAX & 67 & & lubelskie & $3.7 \%(17)$ \\
\hline & $S D$ & 9.84 & & lubuskie & $2.2 \%(10)$ \\
\hline & $b / o$ & 14 & & łódzkie & $6.2 \%(28)$ \\
\hline \multirow{5}{*}{ Education } & Higher education & $90.5 \%(411)$ & & małopolskie & $6.6 \%(30)$ \\
\hline & Secondary & $8.6 \%(39)$ & & mazowieckie & $10.8 \%(49)$ \\
\hline & Primary & $0.4 \%(2)$ & & opolskie & $2.4 \%(11)$ \\
\hline & No education & $0.2 \%(1)$ & & podkarpackie & $9.0 \%(41)$ \\
\hline & $b / o$ & $0.2 \%(1)$ & & podlaskie & $6.6 \%(30)$ \\
\hline \multirow{9}{*}{$\begin{array}{l}\text { Type of work (no } \\
\text { persons) }\end{array}$} & Mean & 12.94 & & pomorskie & $8.4 \%(38)$ \\
\hline & MIN & 1 & & ślq̨skie & $2.9 \%(13)$ \\
\hline & MAX & 52 & & świętokrzyskie & $3.7 \%(17)$ \\
\hline & $S D$ & 10.83 & & warmińsko-mazurskie & $7.0 \%(32)$ \\
\hline & $b / o$ & 11 & & wielkopolskie & $13.2 \%(60)$ \\
\hline & $\begin{array}{l}\text { administrative and } \\
\text { office }\end{array}$ & $72.5 \%(329)$ & & \multirow{4}{*}{ zachodniopomorskie } & \multirow{4}{*}{$2.2 \%(10)$} \\
\hline & managerial & $26.9 \%(122)$ & & & \\
\hline & $\begin{array}{l}\text { Physical work/ } \\
\text { executive }\end{array}$ & $0,4 \%(2)$ & & & \\
\hline & $b / o$ & $0.2 \%(1)$ & & & \\
\hline
\end{tabular}

\section{Measurement Scales}

To measure counterproductive behavior, the validated and adapted to Polish cultural conditions by Szostek (in progress based on the NCN No. 2019/03/X/HS4/00350) scale Counterproductive Work Behavior Checklist (CWB-C), which was originally proposed by Spector et al. (2006) - see Appendix 1. The development of the version of the scale, which can be applied to Central European, and especially Polish, the cultural context was possible thanks to the research carried out by Szostek in 2020, including in-depth group interviews (with experts - theoreticians and management practitioners, as well as with employees), hidden participating observations and an online survey among 1.351 professionally active people in Poland. The interviews made it possible to correct the variables on the CWB-C scale, verify their assignment to CWB-I, CWB-O, and the subject categories distinguished by the authors of the scale (abuse against others, production deviance, theft, sabotage, withdrawal), elimination of incomprehensible or similar semantic variables, as well as adding new variables (examples of 
counterproductive behavior). The observations allowed us to confirm the occurrence of these behaviors in practice. On the other hand, the factor analysis carried out on the basis of the survey results made it possible to select the most important behaviors from the scale, increasing the reliability and validity of this measurement instrument. Moreover, thanks to the factor analysis, it turned out that in the Polish cultural conditions, the scale should consist of four subject categories (the production deviance category was eliminated) (see also Baka et al., 2015). Therefore, the scale used and presented in the current paper is the original and first published contribution from the perspective of the Polish socio-cultural environment.

The Polish version of the scale IPIP-NEO-FFI-50 (International Personality Item Pool NEO-Five Factor Inventory-50; see: Strus et al., 2014) was used to measure personality traits. Initially, the scale was proposed by Goldberg (1992). The scale consists of 50 items divided into 5 personality types (so-called Big Five): Neuroticism, Extraversion, Openness to experience, Agreeableness, and Conscientiousness (see Appendix 2).

\section{Results}

\section{Reliability Values}

A total of 454 correctly completed questionnaires were received, and these were analyzed using IBM SPSS Statistics and IBM SPSS Amos v. 16. The confirmatory factor analysis made it possible to select the variables that made up the personality types and counterproductive behaviors, which shaped a given construct in the most significant way and had the highest factor loadings. It was important from the point of view of the SEM model estimated in the next part. Table 2 presents individual factors with a list of the measurable variables that shape them ( $\mathrm{P}$ - personality traits; $\mathrm{C}-\mathrm{CWB}$; the number next to the variable corresponds to the number on the measurement scale - see Appendixes 1 and 2). The values of the Cronbach's Alpha statistics of the analyzed factors oscillated around the value of 0.7 or higher, which means good reliability of the applied scale (see Pietrzak et al., 2017; Pietrzak, 2017).

Tab. 2. A list of factors with the measurable variables describing them and the Cronbach's Alpha statistics

\begin{tabular}{llc}
\hline \multicolumn{1}{c}{ Factor } & \multicolumn{1}{c}{ The measurable variables } & The Cronbach's Alpha statistics \\
\hline Neuroticism & P11, P16, P31, P36 & 0,762 \\
\hline Extraversion & P7, P17, P27, P47 & 0,778 \\
\hline Openness to experience & P18, P23, P28, P43 & 0,694 \\
\hline Agreeableness & P9, P39, P44, P49 & 0,717 \\
\hline Conscientiousness & P20, P30, P40, P50 & 0,779 \\
\hline CWB-I & C18, C25, C28, C35 & 0,755 \\
\hline CWB-O & C2, C20, C30, C33 & 0,845 \\
\hline
\end{tabular}

In order to verify the hypotheses, the SEM model was estimated using the maximum likelihood method. A significance coefficient of 0.05 was adopted in the model.

The first model, which enables verification of the H1 hypothesis, is a hypothetical model adopted to establish structural relationships between personality types and CWB-O and CWB-I. It also assumed the existence of relationships between the personality traits themselves, without specifying the direction of influence. Only the correlations between personality traits that are substantively justified and statistically significant were left in the model. The diagram itself does not take into account the components of individual factors (measurable variables). In the model, the set of these variables is identical to the list presented in Table 2.

Table 3 contains the results of the maximum likelihood estimation of the external SEM model (factor analysis), Table 4 - the results of this estimation for the internal model (regression analysis), and Table 5 - the values of correlations and covariances included in the model. Table 6 contains measures of the degree of model fit to the data.

Tab. 3. Estimation results of the external SEM model

\begin{tabular}{|c|c|c|c|}
\hline Relationship & Parameter & $\begin{array}{c}\text { Evaluation of } \\
\text { Parameter }\end{array}$ & p-value \\
\hline P11 $\leftarrow$ Neuroticism & $\alpha_{1}$ & 0.473 & \\
\hline P16 $\leftarrow$ Neuroticism & $\alpha_{2}$ & 0.789 & 0.000 \\
\hline $\mathrm{P} 31 \leftarrow$ Neuroticism & $\alpha_{3}$ & 0.665 & 0.000 \\
\hline $\mathrm{P} 36 \leftarrow$ Neuroticism & $\alpha_{4}$ & 0.770 & 0.000 \\
\hline P7 $\leftarrow$ Neuroticism & $\alpha_{5}$ & 0.712 & 0.000 \\
\hline $\mathrm{P} 17 \leftarrow$ Neuroticism & $\alpha_{6}$ & 0.623 & 0.000 \\
\hline P27 $\leftarrow$ Neuroticism & $\alpha_{7}$ & 0.774 & 0.000 \\
\hline P47 $\leftarrow$ Neuroticism & $\alpha_{8}$ & 0.641 & \\
\hline P18 $\leftarrow$ Openness to experience & $\alpha_{9}$ & 0.763 & 0.000 \\
\hline P23 $\leftarrow$ Openness to experience & $\alpha_{10}$ & 0.569 & 0.000 \\
\hline
\end{tabular}




\begin{tabular}{|c|c|c|c|}
\hline P28 $\leftarrow$ Openness to experience & $\alpha_{11}$ & 0.633 & 0.000 \\
\hline P43 $\leftarrow$ Openness to experience & $\alpha_{12}$ & 0.453 & \\
\hline P9 $\leftarrow$ Agreeableness & $\alpha_{13}$ & 0.454 & 0.000 \\
\hline P39 $\leftarrow$ Agreeableness & $\alpha_{14}$ & 0.789 & 0.000 \\
\hline P44 $\leftarrow$ Agreeableness & $\alpha_{15}$ & 0.603 & 0.000 \\
\hline P49 $\leftarrow$ Agreeableness & $\alpha_{16}$ & 0.648 & \\
\hline P20 $\leftarrow$ Conscientiousness & $\alpha_{17}$ & 0.679 & 0.000 \\
\hline P30 $\leftarrow$ Conscientiousness & $\alpha_{18}$ & 0.723 & 0.000 \\
\hline P40 $\leftarrow$ Conscientiousness & $\alpha_{19}$ & 0.734 & 0.000 \\
\hline P50 $\leftarrow$ Conscientiousness & $\alpha_{20}$ & 0.603 & \\
\hline $\mathrm{C} 18 \leftarrow \mathrm{CWB}-\mathrm{I}$ & $\alpha_{21}$ & 0.701 & \\
\hline $\mathrm{C} 25 \leftarrow \mathrm{CWB}-\mathrm{I}$ & $\alpha_{22}$ & 0.676 & 0.000 \\
\hline $\mathrm{C} 28 \leftarrow \mathrm{CWB}-\mathrm{I}$ & $\alpha_{23}$ & 0.693 & 0.000 \\
\hline $\mathrm{C} 35 \leftarrow \mathrm{CWB}-\mathrm{I}$ & $\alpha_{24}$ & 0.608 & 0.000 \\
\hline $\mathrm{C} 2 \leftarrow \mathrm{CWB}-\mathrm{O}$ & $\alpha_{25}$ & 0.776 & \\
\hline $\mathrm{C} 20 \leftarrow \mathrm{CWB}-\mathrm{O}$ & $\alpha_{26}$ & 0.734 & 0.000 \\
\hline $\mathrm{C} 30 \leftarrow \mathrm{CWB}-\mathrm{O}$ & $\alpha_{27}$ & 0.724 & 0.000 \\
\hline $\mathrm{C} 33 \leftarrow \mathrm{CWB}-\mathrm{O}$ & $\alpha_{28}$ & 0.826 & 0.000 \\
\hline
\end{tabular}

Tab. 4. The results of the internal SEM model estimation

\begin{tabular}{lcccc}
\hline \multicolumn{1}{c}{ Relationship } & Parameter & $\begin{array}{c}\text { Evaluation of } \\
\text { parameter }\end{array}$ & $\begin{array}{c}\text { Evaluation of } \\
\text { standardized } \\
\text { parameter }\end{array}$ & p-value \\
\hline Neuroticism $\rightarrow$ CWB_I & $\beta_{1}$ & 0.024 & 0.031 & 0.727 \\
\hline Extraversion $\rightarrow$ CWB_I & $\beta_{2}$ & 0.047 & 0.071 & 0.431 \\
\hline Openness to experience $\rightarrow$ CWB_I & $\beta_{3}$ & 0.039 & 0.043 & 0.541 \\
\hline Agreeableness $\rightarrow$ CWB_I & $\beta_{4}$ & 0.005 & 0.007 & 0.927 \\
\hline Conscientiousness $\rightarrow$ CWB_I & $\beta_{5}$ & 0.016 & 0.026 & 0.706 \\
\hline Neuroticism $\rightarrow$ CWB_O & $\beta_{6}$ & 0.005 & 0.003 & 0.969 \\
\hline Extraversion $\rightarrow$ CWB_O & $\beta_{7}$ & -0.079 & -0.061 & 0.435 \\
\hline Openness to experience $\rightarrow$ CWB_O & $\beta_{8}$ & -0.098 & -0.055 & 0.368 \\
\hline Agreeableness $\rightarrow$ CWB_O & $\beta_{9}$ & 0.189 & 0.145 & 0.035 \\
\hline Conscientiousness $\rightarrow$ CWB_O & $\beta_{10}$ & -0.151 & -0.131 & 0.034 \\
\hline CWB_I $\rightarrow$ CWB_O & $\beta_{11}$ & 0.992 & 0.509 & 0.000 \\
\hline
\end{tabular}

Tab. 5. Values of correlation and covariance included in the SEM model

\begin{tabular}{lcccc}
\hline \multicolumn{1}{c}{ Relationship } & Parameter & Covariance & Correlations & p-value \\
\hline Agreeableness $\leftrightarrow$ Conscientiousness & $\pi_{1}$ & 0.138 & $0.389 \mathrm{~s}$ & 0.000 \\
\hline Openness to experience $\leftrightarrow$ Agreeableness & $\pi_{2}$ & 0.079 & 0.342 & 0.000 \\
\hline Extraversion $\leftrightarrow$ Neuroticism & $\pi_{3}$ & -0.180 & -0.653 & 0.000 \\
\hline
\end{tabular}

\begin{tabular}{ccccc}
\multicolumn{5}{c}{ Tab. 6. Measures of the degree of SEM model fit } \\
\hline Model & IFI & PNFI & RMSEA & CMIN/DF \\
\hline Estimated & 0.851 & 0.652 & 0.064 & 2.868 \\
\hline Saturated & 1 & & & 11.178 \\
\hline Independent & 0 & & 0.150 & \\
\hline
\end{tabular}

The results obtained for the external model (see Table 3) indicate that all factor loadings are statistically significant. Some parameters do not have a p-value provided, which is the result of the inability to calculate it. It is caused by the necessity to assign part of the variables to a constant variance to ensure the model's identifiability (Żurek, 2016).

When interpreting the obtained results (see Table 4), it should be noted that none of the personality types has a direct influence on the CWB-I. In turn, the CWB-O was only statistically significantly influenced by Agreeableness and Conscientiousness. While Agreeableness increases the tendency to CWB-O $\left(\boldsymbol{\beta}_{9}\right)$, on the other side, Conscientiousness reduces such behavior $\left(\boldsymbol{\beta}_{10}\right)$. It should also be noted that the increase in CWB-I behavior is also conducive to the emergence of the second type of behavior, i.e., CWB-O ( $\left.\boldsymbol{\beta}_{11}\right)$. Such a small number of important parameters relating to the influence of individual personality types on CWB behavior may be caused by the heterogeneity of the respondents, which is why the analysis in subgroups was carried out in the following parts. 
When analyzing the correlations between personality types (see Table 5), it can be seen that only the relationship between Neuroticism as a personality trait and Extraversion is negative. In the case of assessment of the degree of fit of the model to empirical data, IFI (Incremental Fit Index) and RMSEA (Root Mean Square Error of Approximation) are usually used. IFI (Incremental Fit Index) is a measure of the relative fit of a given model. IFI values are in the range $<0 ; 1>$, its higher value indicates a better fit of the model to the empirical data (Żurek, 2016; Szostek, 2019b; Balcerzak \& Pietrzak, 2018). RMSEA (Root Mean Square Error of Approximation) is the discrepancy between the theoretical and population matrices of variance-covariance, corrected by the number of degrees of freedom, its values in the range $0.05-0.08$, are considered as the indicator of acceptable fit (Szostek, 2019b; Balcerzak \& Pietrzak, 2018). It should be noted that the value of the IFI is 0.851, while the RMSEA is at the level of 0.064 , which allows for a correct and satisfactory fit of the model to empirical data (see Table 6).

Although the CMIN/DF statistics differ from the commonly accepted norm and is above the value of 2 ( $\mathrm{n}$ the literature it is often recommend to reject models in which CMIN/DF exceeds 2, although many researchers accept less restrictive limits (5 or even 10) (see Bedyńska \& Książek, 2012), it should be remembered that in the case of SEM models each of the model quality measure proposed in the literature has some limitations, and the choice between the accepted measures is often subjective (Żurek, 2016).

In the subsequent paragraphs, the analysis is devoted to the verification of $\mathrm{H} 2$ hypotheses. As it was already stressed, in order to verify the $\mathrm{H} 2$ hypothesis, the model was estimated in a subgroup, taking into account the sex and age of the respondents, seniority, and type of work. The respondents were not divided according to their education, as over $90 \%$ of the respondents completed higher education. The results of the internal SEM model estimation for two groups distinguished on the basis of the respondents' sex are summarized in Table 7.

Tab. 7. The results of estimation of parameters of the internal SEM model in subgroups defined by respondents' sex

\begin{tabular}{|c|c|c|c|c|c|}
\hline \multirow[t]{2}{*}{ Relationship } & \multicolumn{3}{|c|}{ Men } & \multicolumn{2}{|l|}{ Women } \\
\hline & Parameter & $\begin{array}{c}\text { Standardized } \\
\text { Parameter Value }\end{array}$ & p-value & $\begin{array}{c}\text { Standardized } \\
\text { Parameter Value }\end{array}$ & p-value \\
\hline Neuroticism $\rightarrow$ CWB_I & $\beta_{1}$ & 0.081 & 0.422 & 0.000 & 0.999 \\
\hline Extraversion $\rightarrow$ CWB_I & $\beta_{2}$ & 0.186 & 0.069 & -0.174 & 0.321 \\
\hline Openness $\rightarrow$ CWB_I & $\beta_{3}$ & 0.113 & 0.132 & -0.363 & 0.122 \\
\hline Agreeableness $\rightarrow$ CWB_I & $\beta_{4}$ & -0.056 & 0.490 & 0.488 & 0.082 \\
\hline Conscientiousness $\rightarrow$ CWB_I & $\beta_{5}$ & 0.005 & 0.943 & -0.050 & 0.801 \\
\hline Neuroticism $\rightarrow$ CWB_O & $\beta_{6}$ & 0.064 & 0.472 & -0.191 & 0.235 \\
\hline Extraversion $\rightarrow$ CWB_O & $\beta_{7}$ & -0.030 & 0.742 & -0.158 & 0.320 \\
\hline Openness to $\rightarrow$ CWB_O & $\beta_{8}$ & -0.025 & 0.706 & -0.426 & 0.073 \\
\hline Agreeableness $\rightarrow$ CWB_O & $\beta_{9}$ & 0.150 & 0.038 & 0.361 & 0.194 \\
\hline Conscientiousness $\rightarrow$ CWB_O & $\beta_{10}$ & -0.073 & 0.276 & -0.363 & 0.056 \\
\hline CWB_I $\rightarrow$ CWB_O & $\beta_{11}$ & 0519 & 0.000 & 0.367 & 0.014 \\
\hline \multicolumn{2}{|c|}{ Assessment of level of fit } & \multicolumn{2}{|c|}{$\begin{array}{c}\mathrm{IFI}=0.856 \\
\text { RMSEA }=0.065\end{array}$} & \multicolumn{2}{|c|}{$\begin{array}{c}\mathrm{IFI}=0.771 \\
\mathrm{RMSEA}=0.079\end{array}$} \\
\hline
\end{tabular}

Among men, the effect of Conscientiousness on CWB-O $\left(\beta_{10}\right)$ turned out to be statistically insignificant, and in the case of women - the Agreeableness effect $\left(\beta_{9}\right)$ was statistically insignificant. In the group of women, the influence of Agreeableness on CWB-I was also at the borderline of significance $\left(\beta_{4}\right)$ and Openness to experience influence on CWB-O $\left(\beta_{8}\right)$. However, in the case of Openness to experience, it was a negative influence. Additionally, in the case of men, the parameter determining the impact of Extraversion on CWB-I $\left(\beta_{2}\right)$ was slightly outside the confidence interval.

At the next stage, the model for age was estimated. The median age of the respondents was 41 years. Therefore, in order to maintain the greatest possible comparability of the models in subgroups defined on the basis of age, group 1 includes people under 41 years old, and group 2 - people aged 41 and more. The results of the SEM model estimation for both subgroups are presented in Table 8.

Tab. 8. The results of the estimation of parameters of the internal SEM model in subgroups defined on the basis of the respondents' age

\begin{tabular}{lccccc}
\hline \multicolumn{1}{c}{ Relationship } & \multicolumn{2}{c}{ People under 41 years } & \multicolumn{2}{c}{ People aged 41 and more } \\
\hline Parameter & $\begin{array}{c}\text { Standardized } \\
\text { Parameter Value }\end{array}$ & $\begin{array}{c}\text { Standardized } \\
\text { p-value }\end{array}$ & $\begin{array}{c}\text { p-value } \\
\text { Parameter Value }\end{array}$ & 0.876 & 0.090 \\
\hline Extraversion $\rightarrow$ CWB_I & $\beta_{1}$ & -0.017 & 0.535 \\
\hline Openness $\rightarrow$ CWB_I & $\beta_{2}$ & -0.019 & 0.213 & -0.013 \\
\hline Agreeableness $\rightarrow$ CWB_I & $\beta_{3}$ & 0.095 & 0.394 & -0.107 \\
\hline Conscientiousness $\rightarrow$ CWB_I & $\beta_{4}$ & 0.071 & 0.607 & 0.260 \\
\hline
\end{tabular}




\begin{tabular}{lccccc}
\hline Neuroticism $\rightarrow$ CWB_O & $\beta_{6}$ & 0.109 & 0.250 & -0.128 & 0.335 \\
\hline Extraversion $\rightarrow$ CWB_O & $\beta_{7}$ & 0.076 & 0.417 & $\mathbf{- 0 . 2 4 2}$ & $\mathbf{0 . 0 7 7}$ \\
\hline Openness $\rightarrow$ CWB_O & $\beta_{8}$ & -0.094 & 0.322 & 0.055 & 0.505 \\
\hline Agreeableness $\rightarrow$ CWB_O & $\beta_{9}$ & 0.143 & 0.232 & $\mathbf{0 . 1 7 2}$ & $\mathbf{0 . 0 4 6}$ \\
\hline Conscientiousness $\rightarrow$ CWB_O & $\beta_{10}$ & -0.143 & 0.147 & -0.109 & 0.198 \\
\hline CWB_I $\rightarrow$ CWB_O & $\beta_{11}$ & 0.581 & 0.000 & 0.477 & 0.000 \\
\hline \multicolumn{1}{c}{ Assessment of level of fit } & \multicolumn{2}{c}{ IFI $=0.829$} \\
RMSEA $=0.075$ & IFI $=0.843$ \\
& & RMSEA $=0.064$ \\
\hline
\end{tabular}

In this case, the influence of personality traits turned out not to have a significant impact on any type of behavior in the group of people under 41 years old. In the case of older workers, Agreeableness significantly increased the tendency to CWB-O $\left(\beta_{9}\right)$, and Extraversion was on the borderline of statistical significance $\left(\beta_{7}\right)$.

Then, the respondents were also divided according to seniority. The division into groups was based on the median equal to 10 years (see Table 9).

Tab. 9. The results of the estimation of parameters of the internal SEM models for two subgroups based on the seniority

\begin{tabular}{lccccc}
\hline \multicolumn{1}{c}{ Relationship } & \multicolumn{2}{c}{ Seniority less than 10 years } & Seniority $>=10$ \\
& Parameter & $\begin{array}{c}\text { Standardized } \\
\text { Parameter Value }\end{array}$ & p-value & $\begin{array}{c}\text { Standardized } \\
\text { Parameter Value }\end{array}$ & p-value \\
\hline Neuroticism $\rightarrow$ CWB_I & $\beta_{1}$ & 0.120 & 0.315 & 0.072 & 0.611 \\
\hline Extraversion $\rightarrow$ CWB_I & $\beta_{2}$ & -0.051 & 0.672 & 0.163 & 0.254 \\
\hline Openness $\rightarrow$ CWB_I & $\beta_{3}$ & -0.041 & 0.696 & 0.102 & 0.298 \\
\hline Agreeableness $\rightarrow$ CWB_I & $\beta_{4}$ & 0.210 & 0.071 & -0.058 & 0.582 \\
\hline Conscientiousness $\rightarrow$ CWB_I & $\beta_{5}$ & -0.050 & 0.606 & 0.087 & 0.380 \\
\hline Neuroticism $\rightarrow$ CWB_O & $\beta_{6}$ & 0.214 & 0.040 & -0.293 & 0.026 \\
\hline Extraversion $\rightarrow$ CWB_O & $\beta_{7}$ & 0.112 & 0.265 & -0.326 & 0.013 \\
\hline Openness $\rightarrow$ CWB_O & $\beta_{8}$ & 0.086 & 0.326 & -0.112 & 0.199 \\
\hline Agreeableness $\rightarrow$ CWB_O & $\beta_{9}$ & 0.146 & 0.138 & 0.142 & 0.127 \\
\hline Conscientiousness $\rightarrow$ CWB_O & $\beta_{10}$ & -0.192 & 0.023 & -0.112 & 0.196 \\
\hline CWB_I $\rightarrow$ CWB_O & $\beta_{11}$ & 0.455 & 0.000 & 0.590 & 0.000 \\
\hline \multicolumn{1}{c}{ Assessment of level of fit } & \multicolumn{2}{c}{ IFI $=0.829$} \\
\end{tabular}

The obtained results showed that in the case of people working in a given organization for at least 10 years, the influence of Neuroticism on CWB-O was negative, and in the case of people working shorter - it was positive $\left(\beta_{6}\right)$. At the same time, Agreeableness in both groups turned out not to significantly affect CWB-O, while Conscientiousness had an effect only in the first group. Additionally, it is worth stressing that Extraversion significantly increased the tendency to CWB-O in the group of employees with longer employment history $\left(\beta_{6}\right)$.

Finally, the results of the SEM model estimation for the subgroups defined on the basis of type of work are summarized in Table 10. Physical/executive work was omitted due to the small number of respondents in the analyzed subgroup.

Tab. 10. Results of the estimation of the parameters of the SEM internal model in subgroups defined on the basis of type of work

\begin{tabular}{|c|c|c|c|c|c|}
\hline \multirow{2}{*}{$\begin{array}{l}\text { Relationship } \\
\text { Parameter }\end{array}$} & \multirow[b]{2}{*}{$\begin{array}{c}\text { Standardized } \\
\text { Parameter } \\
\text { Value } \\
\end{array}$} & \multicolumn{2}{|c|}{ Administrative / office work } & \multicolumn{2}{|c|}{ Managerial work } \\
\hline & & p-value & $\begin{array}{c}\text { Standardized } \\
\text { Parameter Value }\end{array}$ & p-value & Parameter \\
\hline Neuroticism $\rightarrow$ CWB_I & $\beta_{1}$ & 0.058 & 0.562 & 0.059 & 0.761 \\
\hline Extraversion $\rightarrow$ CWB_I & $\beta_{2}$ & 0.072 & 0.479 & 0.140 & 0.471 \\
\hline Openness $\rightarrow$ CWB_I & $\beta_{3}$ & 0.071 & 0.415 & 0.021 & 0.870 \\
\hline Agreeableness $\rightarrow$ CWB_I & $\beta_{4}$ & 0.041 & 0.674 & -0.113 & 0.404 \\
\hline Conscientiousness $\rightarrow$ CWB_I & $\beta_{5}$ & 0.024 & 0.771 & 0.100 & 0.458 \\
\hline Neuroticism $\rightarrow$ CWB_O & $\beta_{6}$ & 0.018 & 0.841 & -0.120 & 0.480 \\
\hline Extraversion $\rightarrow$ CWB_O & $\beta_{7}$ & -0.017 & 0.853 & -0.309 & 0.077 \\
\hline Openness $\rightarrow$ CWB_O & $\beta_{8}$ & -0.115 & 0.141 & 0.092 & 0.427 \\
\hline Agreeableness $\rightarrow$ CWB_O & $\beta_{9}$ & 0.148 & 0.092 & 0.219 & 0.065 \\
\hline Conscientiousness $\rightarrow$ CWB_O & $\beta_{10}$ & -0.105 & 0.149 & -0.201 & 0.087 \\
\hline CWB_I $\rightarrow$ CWB_O & $\beta_{11}$ & 0.496 & 0.000 & 0.555 & 0.000 \\
\hline \multicolumn{2}{|c|}{ Assessment of level of fit } & \multicolumn{2}{|c|}{$\begin{array}{c}\mathrm{IFI}=0.845 \\
\mathrm{RMSEA}=0.066\end{array}$} & \multicolumn{2}{|c|}{$\begin{array}{c}\mathrm{IFI}=0.837 \\
\mathrm{RMSEA}=0.068\end{array}$} \\
\hline
\end{tabular}


In this case, almost all parameters turned out to have the same direction of impact and significance in both subgroups. The exception was the influence of Extraversion and Conscientiousness on CWB-O, which turned out to be on the borderline of statistical significance only in the subgroup of respondents in managerial positions $\left(\beta_{7}\right.$ i $\left.\beta_{10}\right)$.

\section{Discussion, main limitations, and future studies}

Referring to the presented results of the SEM model estimations, it can be stated that the strongest predictor of organizational CWB was Agreeableness and Conscientiousness. In the former case, the relationship is positive, and in the latter - negative. This should come as no surprise, as Employees who are highly assessed in terms of Conscientiousness tend to avoid CWB, which Ones and Viswesvaran (2001) previously suggested. On the other hand, agreeable employees are empathetic and try not to enter into conflicts; hence a negative relationship between this personality type and CWB-I would seem natural, but what is interesting here, the analysis of the obtained results did not confirm this.

The obtained research results are conducive with Salgado's (2002) meta-analysis, which was based on a database that was developed for American and European validity studies published in behavioral sciences journals in the years 1990-1999, where correlations of Neuroticism, Agreeableness, and Conscientiousness with CWB ranged from 0.06 to 0.26 . The results are also consistent with the contribution provided by Lee et al. (2005a) research, which was based on the samples obtained for Australia, Canada, and the Netherlands, where Agreeableness was correlated with CBW-I and Conscientiousness - with CWB-O.

A study presented by Mount et al. (2006), which was done base on the sample of 141 employees in customer service positions in 10 fast food stores of a large national chain, showed that CWB-O was strongly correlated with Conscientiousness ( $r=-0.55)$, while CWB-I - with Agreeableness $(r=-0.48)$. That outcome can also be considered as partially conducive to the results presented in current research for Polish employees. The similarity also occurs with the results of a study given by Berry et al. (2007). In their meta-analysis, the authors stated that there is the strongest correlation between Agreeableness and CWB-I $(r=-0.46)$ and between Conscientiousness and CWB-O $(\mathrm{r}=-0.42)$. According to these authors, also Neuroticism was statistically significantly correlated with CWB-O $(r=0.23)$ and CWB-I $(r=0.24)$. Statistically insignificant was the impact of Extraversion and Openness to expercience on CWB.

The demographic variables included in the measurement, i.e., sex and age of the respondents, as well as the length of employment and type of work, moderated statistically significantly the relationship between personality traits and CWB-O and CWB-I. This allows for challenging the opinion of Miller et al. (2003), who analyzed the sample composed of 481 participants who were part of the Lexington Longitudinal Study and found that there were no significant gender differences for any of the analyzed correlations between personality traits and CWB.

The current research is not free of limitations, which should be stressed in the discussion of the obtained results. These limitations, at the same time, provide an important starting point for future research. First of all, the primary area of criticism must be directed to the sample selection. The sample was relatively large and demographically diverse, but it was non-random. Therefore, the first area of potential future improvements of the current study is conducting this research with a random sample. Besides, it would seem important to differentiate more the sample by sex and education.

In the case of evaluation of CWB, it would be better to use both self-reports and supervisor reports (Mount et al., 2006), where these measurements should be complementary (Lee et al., 2005a). Employees are especially reluctant to self-report on CWB because of the potential fear of reprimands (Skarlicki et al., 1999). As a result, the measurement must be rather anonymous. Additionally, it would be better to use also other's people ratings of CWB to minimize the common method bias problem. However, observations conducted by others also have some limitations (Skarlicki et al., 1999). It is obvious that not all manifestations of CWB can be observed. However, it can be concluded that future research could be built on self-reports and supervisor/colleagues' reports.

Another area of important potential critics can be attributed to the models applied in the current study. The presented models may always be considered as underspecified, as some other perceptual variables could moderate some of the relationships. It must be remembered that various variables (not only individual but also situational) can influence CWB. In the future, the models should be expanded with such variables.

Finally, the potential limitations can also be related to the scope of current research, as there are many other forms of CWB that could be considered counterproductive and that bring high both microeconomic and social costs. Therefore, future research should broaden the measurement of CWB significantly to include other behaviors. 


\section{Conclusions}

The current research concentrated on the empirical literature gap on the relation between personality traits and counterproductive behavior within the context of Central European and, strictly speaking, Polish cultural and social context. The main goal of the article was to determine how the five personality traits, namely Extraversion, Neuroticism, Conscientiousness, Agreeableness, and Openness to experience, can influence the extent of organizational and interpersonal counterproductive work behaviors (CWB; CWB-O; CWB-I) and how these relations are moderated by the demographic and professional characteristics of employees (sex, age, seniority or type of work). The current study determined that personality traits strongly affect counterproductive work behaviors. What is also important here, the relationship between personality traits and CWB-O/I was significantly moderated by the demographic and professional characteristics of employees taken into account (sex, age, seniority, or type of work).

In the case of Polish and with broader perspective Central European cultural and social context, one can indicate the following practical implications of the current research, which to some extent can be compared to previous studies provided by Mount et al. (2006):

- for employee selection - selecting employees with high scours indicating Conscientiousness is likely to reduce the occurrence of $\mathrm{CWB}-\mathrm{O}$,

- for organizational training programs - such training should include a component that conveys to managers the pervasiveness and expense associated with CWBs,

- for rating employee performance - there is a "halo effect" in manager's ratings of the types of CWBs,

- for detection of CWBs - CWB-O are less observable than CWB-I. Therefore, many organizations may benefit from the development of electronic monitoring systems specifically designed to detect organizational CWB.

To sum up the presented outcome, it should be stressed that from the practical perspective, the obtained results can be especially important for human resource management in the reality of the growing role of effective relations among employees in the context of the Industry 4.0 challenges.

\section{References}

Abdillah, M.R., Lin, C.-T., Anita, R., Suroto, B., \& Hadiyati. (2018). Knowledge sharing behavior among banking officers in Indonesia. Journal of International Studies, 11(2), 136-153. doi:10.14254/2071$8330.2018 / 11-2 / 10$.

Ahmed, R. R., Romeika, G., Kauliene, R., Streimikis, J., \& Dapkus, R. (2020). ES-QUAL model and customer satisfaction in online banking: evidence from multivariate analysis techniques. Oeconomia Copernicana, 11(1), 59-93. doi: 10.24136/oc.2020.003.

Anyakoha, C. (2019). Job analysis as a tool for improved organizational performance of SMEs in Lagos, Nigeria. Central European Journal of Labour Law and Personnel Management, 2(1), 7-16. doi: 10.33382/cejllpm.2019.02.01

Babikova, K., \& Bucek, J. (2019). A Model Replication with an Extension of Students' Perception of Prospective Employer Attractiveness. Journal of Competitiveness, 11(2), 5-21. doi: 10.7441/joc.2019.02.01.

Baka, Ł., Derbis, R., \& Walczak, R. (2015). Psychometryczne właściwości Kwestionariusza Zachowań Kontrproduktywnych CWB-C. Czasopismo Psychologiczne, 21(2), 163-174. doi: 10.14691/CPPJ.21.2.163.

Balcerzak, A.P. (2020). Quality of institutions in the European Union countries. Application of TOPSIS based on entropy measure for objective weighting. Acta Polytechnica Hungarica, 17(1), 101-122. doi: 10.12700/APH.17.1.2020.1.6.

Balcerzak, A. B., \& MacGregor Pelikánová, R. (2020). Projection of SDGs in Codes of Ethics-Case Study about Lost in Translation. Administrative Sciences, 10(4), 95.

Balcerzak, A. P., \& Pietrzak, M. B. (2018). Relations among Social and Economic Order in European Union Countries. In M. H. Bilgin, H. Danis, E. Demir, U. Can (eds) (Eds.). Eurasian Business Perspectives. Eurasian Studies in Business and Economics, Proceedings of the 20th Eurasia Business and Economics Society. vol 8/2 Springer, Cham, pp. 385-396. doi: 10.1007/978-3-319-67916-7_25.

Bechtoldt, M. N., Welk, C., Zapf, D., \& Hartig, J. (2007). Main and moderating effects of self-control, organizational justice, and emotional labour on counterproductive behaviour at work. European Journal of Work and Organizational Psychology, 16(4), 479-500. doi: 10.1080/13594320701662618

Bedyńska, S., \& Książek, M. (2012). Statystyczny drogowskaz 3. Praktyczny przewodnik wykorzystania modeli regresji oraz równań strukturalnych. Wydawnictwo Akademickie Sedno, Warszawa. 
Belas, J., Amoah, J., Petráková, Z., Kliuchnikava, Y., Bilan, Y. (2020). Selected Factors of SMEs Management in the Service Sector. Journal of Tourism and Services, 21(11), 129-146. doi: 10.29036/jots.v11i21.215.

Bernardi, A. (2019). The capability approach and organizational climate as tools to study occupational health and safety. Insights into Regional Development, 1(2), 155-169. doi: 10.9770/ird.2019.1.2(6)

Berry, C. M., Ones, D. S., \& Sackett, P. R. (2007). Interpersonal deviance, organizational deviance, and their common correlates: A review and meta-analysis. Journal of Applied Psychology, 92(2), 410-424. doi: 10.1037/0021-9010.92.2.410.

Bilan Y., Mishchuk, H., Roshchyk, I. \& Joshi, O. (2020). Hiring and retaining skilled employees in SMEs: problems in human resource practices and links with organizational success. Business: Theory and Practice, 21(2), 780-791. doi: 10.3846/btp.2020.12750

Brycz, H., Konarski, R., Kleka, P., \& Wright, R. (2019). The metacognitive self: the role of motivation and an updated measurement tool. Economics and Sociology, 12(1), 208-232. doi: 10.14254/2071789X.2019/12-1/12.

Case, J. (2000), Employee theft: The profit killer, Del Mar, CA: John Case \& Associates.

Cismas, L.M., Miculescu, A., Negrut, L., Negrut, V., Otil, M.D., Vadasan, I. (2019). Social Capital, Social Responsibility, Economic Behavior and Sustainable Economic Development - An Analysis of Romania's Situation", Transformations in Business \& Economics, 18(No 2A (47A)), 605-627.

Coffin, B. (2003). Breaking the silence on white collar crime. Risk Management, 50(9), 8

Collins, J. M., \& Schmidt, F. L. (1993). Personality, integrity, and white collar crime: A construct validity study. Personnel Psychology, 46(2), 295-311. doi: 10.1111/j.1744-6570.1993.tb00875.x.

Costa, P. T., \& McCrae, R. R. (1988). Personality in adulthood: A six-year longitudinal of self-reports and spouse ratings on the NEO Personality Inventory. Journal of Personality and Social Psychology, 54(5), 853-863. doi:: 10.1037//0022-3514.54.5.853.

Costa, P. T., \& McCrae, R. R. (1990). Personality disorders and the five-factor model of personality. Journal of Personality Disorders, 4(4), 362-371. doi:: 10.1521/pedi.1990.4.4.362.

Costa, P. T., McCrae, R. R., \& Dye, D. A. (1991). Facet scales for agreeableness and conscientiousness: A revision of the NEO Personality Inventory. Personality and Individual Differences, 12(9), 887-898. doi: 10.1016/0191-8869(91)90177-D.

Czerwonka, M. (2019). Cultural, cognitive and personality traits in risk-taking behaviour: evidence from Poland and the United States of America. Economic Research-Ekonomska Istraživanja, 32(1), 894-908, doi: 10.1080/1331677X.2019.1588766.

Douglas, S. C., \& Martinko, M. J. (2001). Exploring the role of individual differences in the prediction of workplace aggression. Journal of Applied Psychology, 86(4), 547-559. doi: 10.1037/0021-9010.86.4.547.

Dvorský, J., Petráková, Z., Fialová, V. (2020). Perception of Business Risks by Entrepreneurs According to Experience with the Business Failure. International Journal of Entrepreneurial Knowledge, 8(1), 76-88. doi: $10.37335 /$ ijek.v8i1.104.

Erjavec, J., Popovič,_A., \& Trkman, P. (2019). The effect of personality traits and knowledge on the quality of decisions in supply chains. Economic Research-Ekonomska Istraživanja, 32(1), 2269-2292, doi: 10.1080/1331677X.2019.1642788

Everton, W. J., Jolton, J. A., \& Mastrangelo, P. M. (2007). Be nice and fair or else: understanding reasons for employees' deviant behaviors. Journal of Management Development, 26(2), 117-131. doi:10.1108/02621710710726035.

Fehr, R., Yam, K. Ch., He W., Ting-Ju Chian, J., \& Wei W. (2017). Polluted work: A self-control perspective on air pollution appraisals, organizational citizenship, and counterproductive work behavior. Organizational Behavior and Human Decision Processes, 143, 98-110. doi: 10.1016/j.obhdp.2017.02.002.

Ferreira, M. F., \& Nascimento, E. (2016). Relationship between personality traits and counterproductive work behaviors. Psico-USF, Bragança Paulista, 21(3), 677-685. doi: 10.1590/1413-82712016210319.

Furnham, A., \& Miller, T. (1997). Personality, absenteeism and productivity. Personality and Individual Differences, 23(4), 705-707. doi: 10.1016/S0191-8869(97)00092-5.

Goldberg, L. R. (1992). The development of markers of the Big Five factor structure, Psychological Assessment, 4(1), 26-42. doi: 10.1037/1040-3590.4.1.26.

Gruys, M. L., \& Sackett, P. R. (2003). Investigating the dimensionality of counterproductive work behawior, International Journal of Selection and Assessment, 11(1), 30-42. doi: 10.1111/1468-2389.00224.

Heaven, P. C. L. (1996). Personality and Self-Reported Delinquency: A Longitudinal Analysis. Journal of Child Psychology and Psychiatry, 37(6), 747-751. doi: 10.1111/j.1469-7610.1996.tb01467.x.

Hitka, M., Lorincová, S., Vetráková, M., Hajdúchová, I., Antalík, I. (2020). Factors related to gender and education affecting the employee motivation. Entrepreneurship and Sustainability Issues, 7(4), 32263241. doi: 10.9770/jesi.2020.7.4(43) 
Hoel, H., Einarsen, S., \& Cooper, C. L. (2003). Organizational effects of bullying. In S. Einarsen, H. Hoel, D. Zapf, \& C. Cooper (Eds.). Bullying and emotional abuse in the workplace: International perspectives on research and practice. London: Taylor \& Francis.

Hollinger, R. C., \& Clark, J. P. (1982). Formal and informal social controls of employee deviance. Sociological Quarterly, 23(3), 333-343. https://doi.org/10.1111/j.1533-8525.1982.tb01016.x.

Hough, L. M. (1992). The 'Big Five' personality variables-construct confusion: Description versus prediction. Human Performance, 5(1-2), 139-155. doi: 10.1080/08959285.1992.9667929.

Hunt, S. T. (1996). Generic work behavior: An investigation into the dimensions of entry-level, hourly job performance. Personnel Psychology, 49(1), 51-83. doi: 10.1111/j.1744-6570.1996.tb01791.x.

Hussain, H.I., Kot, S., Kamarudin, F., Mun, W.C. (2020). The nexus of competition freedom and the efficiency of microfinance institutions. Journal of Competitiveness, 12(2), 67-89. doi: 10.7441/joc.2020.02.05.

Iverson, R. D., \& Erwin, P. J. (1997). Predicting occupational injury: The role of affectivity. Journal of Occupational and Organizational Psychology, 70(2), 113-128. doi: 10.1111/j.2044-8325.1997.tb00637.x.

Jędrzejczak-Gas, J., \& Wyrwa, J. (2020). Determinants of job satisfaction in a transport company: a Polish case study. Equilibrium. Quarterly Journal of Economics and Economic Policy, 15(3), 565-593. doi: 10.24136/eq.2020.025.

Judge, T. A., Martocchio, J. J., \& Thoresen, C. J. (1997). Five-factor model of personality and employee absence. Journal of Applied Psychology, 82(5), 745-755. doi: 10.1037/0021-9010.82.5.745.

Kot, S., Ul Haque, A., Baloch, A. (2020). Supply chain management in SMEs: Global perspective. Montenegrin Journal of Economics, 16(1), 87-104. doi: 10.14254/1800-5845/2020.16-1.6

Krischer, M. M., Penney, L. M., \& Hunterz, E. M. (2010). Can counterproductive work behaviors be productive? CWB as emotion-focused coping. Journal of Occupational Health Psychology, 15(2), 154-166. doi: $10.1037 / \mathrm{a} 0018349$.

Kwok, C.-K., Au, W. T., \& Ho, J. M. C. (2005). Normative controls and self -reported counterproductive behaviors in the workplace in China. Applied Psychology: An International Review, 54(4), 456-475. doi: 10.1111/j.1464-0597.2005.00220.x.

Kwahar, N., \& Iyortsuun, A. (2018). Determining the Underlying Dimensions of Quality of Work Life (QWL) in the Nigerian Hotel Industry. Entrepreneurial Business and Economics Review, 6(1), 53-70. doi: 10.15678/EBER.2018.060103.

Laužikas, M., \& Miliūtè, A. (2020). Human resource management effects on sustainability of high-tech companies: what Lithuania and South Korea can learn from each other. Insights into Regional Development, 2(2), 562-579. doi: 10.9770/IRD.2020.2.2(5)

Lee, K., Ashton, M. C., \& de Vries, R. E. (2005b). Predicting Workplace Delinquency and Integrity with the HEXACO and Five-Factor Models of Personality Structure. Human Performance, 18(2), pp. 179-197. doi: $10.1207 / \mathrm{s} 15327043 \mathrm{hup} 18024$.

Lee, K., Ashton, M. C., \& Shin, K.-H. (2005a). Personality Correlates of Workplace Anti-Social Behavior. Applied Psychology: An International Review, 54(1), 81-98. doi: 10.1111/j.1464-0597.2005.00197.x.

Marcus, B., Lee, K., \& Ashton, M. C. (2007). Personality dimensions explaining relationships between integrity tests and counterproductive behavior: Big five, or one in addition? Personnel Psychology, 60(1), 1-34. doi: $10.1111 / \mathrm{j} .1744-6570.2007 .00063 . x$.

Miller, J. D., \& Lynam, D. (2001). Structural models of personality and their relation to antisocial behavior: A meta-analytic review. Criminology, 39(4), 765-798. doi: 10.1111/j.1745-9125.2001.tb00940.x.

Miller, J. D., Lynam, D., \& Leukefeld, C. (2003). Examining antisocial behavior through the lens of the Five Factor Model of personality. Aggressive Behavior, 29(6), 497-514. doi: 10.1002/ab.10064.

Molose, T., Goldman, G., \& Thomas, P. (2018). Towards a Collective-Values Framework of Ubuntu: Implications for Workplace Commitment. Entrepreneurial Business and Economics Review, 6(3), 193206. doi: 10.15678/EBER.2018.060312.

Mount, M., Ilies, R., \& Johnson, E. (2006). Relationship of personality traits and counterproductive work behaviors: The mediating effects of job satisfaction. Personnel Psychology, 59(3), 591-622. doi: 10.1111/j.1744-6570.2006.00048.x.

Murphy, K. R. (1993). Honesty in the workplace. Belmont, CA: Brooks/Cole.

Mura, L., Gontkovicova, B., Dulova Spisakova, E., Hajduova, Z. (2019). Position of Employee Benefits in Remuneration Structure. Transformations in Business \& Economics, Vol. 18, No 2 (47), pp.156-173.

Ng, T. H., \& Feldman, D. C. (2009). How broadly does education contribute to job performance? Personnel Psychology, 62(1), 89-134. doi: 10.1111/j.1744-6570.2008.01130.x.

Ones, D. S., \& Viswesvaran, C. (2001). Integrity tests and other criterion-focused occupational personality scales (COPS) used in personnel selection, International Journal of Selection and Assessment, 9(1-2), 31-39. doi: 10.1111/1468-2389.00161.

Ones, D. S., Viswesvaran, C., \& Schmidt, F. L. (2003). Personality and absenteeism: A meta-analysis of integrity tests. European Journal of Personality, 17 (Supplement 1), 19-38. doi: 10.1002/per.487. 
Pekerşen, Y., Tugay, O (2020). Professional Satisfaction as a Key Factor in Employee Retention: A case of the Service Sector. Journal of Tourism and Services, 20(11), 1-27. doi: 10.29036/jots.v11i20.123.

Pietrzak, M. B. (2017). Structural Equation Modeling of Regional Economic Development in Polish Voivodeships in the Years 2010-2014. In T. Loster \& T. Pavelka (Eds.). The 11th International Days of Statistics and Economics. Conference Proceedings. September 8-10, 2016. Prague: Libuse Macakova, Melandrium, 1214-1222.

Pietrzak, M. B., Balcerzak, A. P., Gajdos, A., \& Arendt, Ł (2017). Entrepreneurial environment at regional level: the case of Polish path towards sustainable socio-economic development. Entrepreneurship and Sustainability Issues, 5(2). 190-203, doi: 10.9770/jesi.2017.5.2(2).

Pilelienè, L., \& Grigaliūnaite, V. (2017). Colour temperature in advertising and its impact on consumer purchase intentions. Oeconomia Copernicana, 8(4), 657-669. doi: 10.24136/oc.v8i4.40.

Pisar, P., \& Bilkova, D. (2019). Controlling as a tool for SME management with an emphasis on innovations in the context of Industry 4.0. Equilibrium. Quarterly Journal of Economics and Economic Policy, 14(4), 763-785. doi: 10.24136/eq.2019.035.

Robinson, S. L., \& Bennett, R. J. (1995). A typology of deviant workplace behaviors: A multidimensional scaling study. Academy of Management Journal, 38(2), pp. 555-752. doi: 10.2307/256693.

Rogalska, E., \& Kuc-Czarnecka, M. (2020). A Structural Equation Modeling Approach to Study Social Exclusion in Poland. In K. S. Soliman (Ed.). Proceedings of the 35rd International Business Information Management Association Conference (IBIMA). 1-2 April 2020, Seville, Spain. Education Excellence and Innovation Management: A 2025 Vision to Sustain Economic Development during Global Challenges. International Business Information Management Association (IBIMA), 9128-9138.

Rozsa, Z., Formánek, I., Maňák, R. (2019). Determining the factors of the employees' intention to stay or leave in the Slovak's SMEs. International Journal of Entrepreneurial Knowledge, 7(2), 63-72. doi: 10.37335/ijek.v7i2.94.

Salami, S. O. (2010). Job stress and counterproductive work behaviour: Negative affectivity as a moderator. Social Sciences, 5(6), 486-492. DOI: 10.3923/sscience.2010.486.492.

Salgado, J. F. (2002). The Big Five personality dimensions and counterproductive behaviors. International Journal of Selection and Assessment, 10(1/2), 117-125. doi: 10.1111/1468-2389.00198.

Schmidt, F. L., Ones, D. S., \& Viswesvaran, C. (1997). Validity of Integrity Tests for Predicting Drug and Alcohol Abuse. NIDA Research Monograph, 170, 69-95.

Seilerová, M. (2019). The Consequences of Psychosocial Risks in the Workplace in Legal Context. Central European Journal of Labour Law and Personnel Management, 2(1), 47-60. doi: 10.33382/cejllpm.2019.02.04

Skarlicki, D. P., Folger, R., \& Tesluk, P. (1999). Personality as a moderator in the relationship between fairness and retaliation. Academy of Management Journal, 42(1), 100-108. doi: 10.2307/256877.

Spector, P. E., \& Fox, S. (2010). Counterproductive work behavior and organizational citizenship behavior: Are they opposite forms of active behavior? Applied Psychology: An International Review, 59(1), pp. 21-39. doi: 10.1111/j.1464-0597.2009.00414.x.

Spector, P. E., Fox, S., Penney, L. M., Bruursema, K., Goh, A., \& Kessler, S. (2006). The dimensionality of counterproductivity: Are all counterproductive behaviors created equal? Journal of Vocational Behavior, 68, 446-460. doi:10.1016/j.jvb.2005.10.005.

Sroka, W., \& Vveinhardt, J. (2020). Nepotism and favouritism: How harmful are these phenomena? Forum Scientiae Oeconomia, 8(2), 79-91. doi: 10.23762/FSO_VOL8_NO2_5.

Stelmaszczyk, M. (2020). How Absorptive Capacity and Organisational Learning Orientation Interact to Enable Innovation Capability? An Empirical Examination. Entrepreneurial Business and Economics Review, 8(1), 7-32. doi: 10.15678/EBER.2020.080101

Strus, W., Cieciuch, J., \& Rowiński, T. (2014). The Polish adaptation of the IPIP-BFM-50 questionnaire for measuring five personality traits in the lexical approach, Roczniki Psychologiczne/Annals of Psychology, $17(2), 347-366$.

Szostek, D. (2019a). Kontrproduktywne zachowania organizacyjne $w$ kontekście jakości relacji interpersonalnych $w$ zespołach pracowniczych. Torun: Wydawnictwo Naukowe UMK.

Szostek, D. (2019b). The impact of the quality of interpersonal relationships between employees on counterproductive work behavior: A study of employees in Poland. Sustainability, 11(21), 1-33. doi: $10.3390 /$ su11215916.

Tellegen, A. (1993). Folk concepts and psychological concepts of personality and personality disorder. Psychological Inquiry, 4(2), 122-130. doi: 10.1207/s15327965pli0402_12.

ul Haque, A., Sher, A., \& Urbański, M. (2020). Is the role of authentic leadership effective in managing occupational stress and psychological capital? Forum Scientiae Oeconomia, 8(2), 59-77. doi: $10.23762 /$ FSO VOL8 NO2 4

Vardi, Y., \& Weitz, E. (2004). Misbehavior in Organizations. Lawrence Elbaum Associates, New Jersey. 
Wroblowska, Z. (2019). Personality Requirements for Ukrainian and Czech Managers Creating Brands as a Competitive Advanatage. Journal of Competitiveness, 11(1), 152-167. doi: 10.7441/joc.2019.01.10.

Vveinhardt, J, \& Sroka, W. (2020). Mobbing and Corporate Social Responsibility: does the status of the organization guarantee employee wellbeing and intentions to stay in the job? Oeconomia Copernicana, 11(4).

Żurek, M. (2016). Inklinacje behawioralne na rynkach kapitałowych $w$ świetle modeli SEM, Toruń: Wydawnictwo Naukowe Uniwersytetu Mikołaja Kopernika.

\begin{tabular}{|c|c|c|c|c|c|}
\hline $\begin{array}{l}\text { How often have you undertaken the behaviors listed below in your current job? } \\
\text { (please respond to each of them) }\end{array}$ & $\stackrel{\vec{D}}{\overrightarrow{0}}$ & $\begin{array}{l}\mathscr{\Xi} \\
\stackrel{\Xi}{\Xi} \\
\stackrel{N}{\longrightarrow}\end{array}$ & 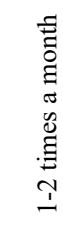 & 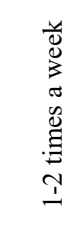 & 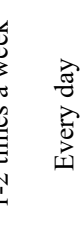 \\
\hline 1. I have intentionally wasted my employer's materials/funds & $1 \square$ & $2 \square$ & $3 \square$ & $4 \square$ & $5 \square$ \\
\hline 2. I was wasting my time instead of doing my job & $1 \square$ & $2 \square$ & $3 \square$ & $4 \square$ & $5 \square$ \\
\hline 3. I complained to others about the company or work in it & $1 \square$ & $2 \square$ & $3 \square$ & $4 \square$ & $5 \square$ \\
\hline 4. I told people outside the company that this is a poor place to work & $1 \square$ & $2 \square$ & $3 \square$ & $4 \square$ & $5 \square$ \\
\hline 5. I was late for work or left/left work early without permission & $1 \square$ & $2 \square$ & $3 \square$ & $4 \square$ & $5 \square$ \\
\hline 6. I stayed at home saying that I was sick when I was not & $1 \square$ & $2 \square$ & $3 \square$ & $4 \square$ & $5 \square$ \\
\hline 7. I have intentionally destroyed company property & $1 \square$ & $2 \square$ & $3 \square$ & $4 \square$ & $5 \square$ \\
\hline 8. I have littering my workplace on purpose & $1 \square$ & $2 \square$ & $3 \square$ & $4 \square$ & $5 \square$ \\
\hline 9. I have appropriated something belonging to the company & $1 \square$ & $2 \square$ & $3 \square$ & $4 \square$ & $5 \square$ \\
\hline 10. I spread a rumor that is harmful to someone at work & $1 \square$ & $2 \square$ & $3 \square$ & $4 \square$ & $5 \square$ \\
\hline 11. I was working slowly on purpose when something was supposed to be done quickly & $1 \square$ & $2 \square$ & $3 \square$ & $4 \square$ & $5 \square$ \\
\hline 12. Without a justified reason, I have refused to accept the assigned task & $1 \square$ & $2 \square$ & $3 \square$ & $4 \square$ & $5 \square$ \\
\hline 13. I was late for the meeting on purpose & $1 \square$ & $2 \square$ & $3 \square$ & $4 \square$ & $5 \square$ \\
\hline 14. I did not report any problem, which made the situation worse & $1 \square$ & $2 \square$ & $3 \square$ & $4 \square$ & $5 \square$ \\
\hline 15. I took a longer break than I was allowed to & $1 \square$ & $2 \square$ & $3 \square$ & $4 \square$ & $5 \square$ \\
\hline 16. I did not follow the instructions/instructions on purpose & $1 \square$ & $2 \square$ & $3 \square$ & $4 \square$ & $5 \square$ \\
\hline 17. I have intentionally offended someone at work & $1 \square$ & $2 \square$ & $3 \square$ & $4 \square$ & $5 \square$ \\
\hline 18. I mocked someone's personal life & $1 \square$ & $2 \square$ & $3 \square$ & $4 \square$ & $5 \square$ \\
\hline 19. I took company materials or tools home without permission & $1 \square$ & $2 \square$ & $3 \square$ & $4 \square$ & $5 \square$ \\
\hline 20. I was pretending that I was busy without really doing anything important & $1 \square$ & $2 \square$ & $3 \square$ & $4 \square$ & $5 \square$ \\
\hline 21. I applied for payment for more hours than I worked & $1 \square$ & $2 \square$ & $3 \square$ & $4 \square$ & $5 \square$ \\
\hline 22. I have appropriated my employer's money & $1 \square$ & $2 \square$ & $3 \square$ & $4 \square$ & $5 \square$ \\
\hline 23. I have ignored someone at work & $1 \square$ & $2 \square$ & $3 \square$ & $4 \square$ & $5 \square$ \\
\hline 24. I interfered in someone's work without permission & $1 \square$ & $2 \square$ & $3 \square$ & $4 \square$ & $5 \square$ \\
\hline 25. I provoked a quarrel/argument with someone at work & $1 \square$ & $2 \square$ & $3 \square$ & $4 \square$ & $5 \square$ \\
\hline 26. I have appropriated to myself something that belonged to someone at work & $1 \square$ & $2 \square$ & $3 \square$ & $4 \square$ & $5 \square$ \\
\hline 27. I have threatened someone at work & $1 \square$ & $2 \square$ & $3 \square$ & $4 \square$ & $5 \square$ \\
\hline 28. I have told someone at work something to make them feel bad & $1 \square$ & $2 \square$ & $3 \square$ & $4 \square$ & $5 \square$ \\
\hline 29. I did not call someone at work whom I was supposed to call back & $1 \square$ & $2 \square$ & $3 \square$ & $4 \square$ & $5 \square$ \\
\hline 30. I have handled private matters during my work & $1 \square$ & $2 \square$ & $3 \square$ & $4 \square$ & $5 \square$ \\
\hline 31. I have knowingly cheated or lied to someone at work & $1 \square$ & $2 \square$ & $3 \square$ & $4 \square$ & $5 \square$ \\
\hline 32. I was blackmailing someone at work & $1 \square$ & $2 \square$ & $3 \square$ & $4 \square$ & $5 \square$ \\
\hline 33. Instead of working, I spent time on the Internet (for example, I was browsing the profile on social & $1 \square$ & $2 \square$ & $3 \square$ & $4 \square$ & $5 \square$ \\
\hline 34. I have attributed to myself the merits of another person from work & $1 \square$ & $2 \square$ & $3 \square$ & $4 \square$ & $5 \square$ \\
\hline 35. I have manipulated other people at work & $1 \square$ & $2 \square$ & $3 \square$ & $4 \square$ & $5 \square$ \\
\hline
\end{tabular}

Sabotage: $1,3,4,5,7,8,14$,

Withdrawal: $2,5,6,11-13,15,20,29,30,33$

Theft: 9, 19, 21, 22, 26

Abuse against others: $10,17,18,23-25,27,28,31,32,34,35$

CWB-O: 1-9, 11-16, 19-22, 30, 33

CWB-I: 10, 17, 18, 23-28, 29, 31, 32, 34, 35

Source: Szostek (in progress based on the NCN No. 2019/03/X/HS4/00350). 
Appendix 2. International Personality Item Pool NEO-Five Factor Inventory-50

Read carefully the following sentences that describe people's different behaviors, feelings, and thoughts. Think about each of them - to what extent does it also describe you as you usually are? People are very different, so there are no right or wrong answers here. Simply answer each time honestly to what extent the statement describes you

(1 - describes me completely incorrectly, 2 - describes me rather incorrectly, 3 - a bit accurate and a bit inaccurate describes me, 4 - describes me rather accurately, 5 - describes me completely)

\begin{tabular}{|c|c|c|c|c|c|}
\hline 1. I often have mood swings & 1 & 2 & 3 & 4 & 5 \\
\hline I stay aside & 1 & 2 & 3 & 4 & 5 \\
\hline I have a vivid imagination & 1 & 2 & 3 & 4 & 5 \\
\hline 4. I can hurt others & 1 & 2 & 3 & 4 & 5 \\
\hline 5. I make plans and stick to them closely & 1 & 2 & 3 & 4 & 5 \\
\hline 6. It is difficult to alarm me with something & 1 & 2 & 3 & 4 & 5 \\
\hline 7. I feel great among people & 1 & 2 & 3 & 4 & 5 \\
\hline 8. I avoid philosophical discussions & 1 & 2 & 3 & 4 & 5 \\
\hline 9. In my company, others feel at ease & 1 & 2 & 3 & 4 & 5 \\
\hline 10. I only do as much as I need to & 1 & 2 & 3 & 4 & 5 \\
\hline 11. I am often depressed & 1 & 2 & 3 & 4 & 5 \\
\hline 12. I have little to say & 1 & 2 & 3 & 4 & 5 \\
\hline 13. I am inclined to vote for liberal politicians & 1 & 2 & 3 & 4 & 5 \\
\hline 14. I play on others & 1 & 2 & 3 & 4 & 5 \\
\hline 15. I systematically implement what I have planned & 1 & 2 & 3 & 4 & 5 \\
\hline 16. I am pleased with myself & 1 & 2 & 3 & 4 & 5 \\
\hline 17. I make friends easily & 1 & 2 & 3 & 4 & 5 \\
\hline 18. I don't like art & 1 & 2 & 3 & 4 & 5 \\
\hline 19. I believe others have good intentions & 1 & 2 & 3 & 4 & 5 \\
\hline 20. I don't bring things to the end & 1 & 2 & 3 & 4 & 5 \\
\hline 21. I often get depressed & 1 & 2 & 3 & 4 & 5 \\
\hline 22. I don't say much & 1 & 2 & 3 & 4 & 5 \\
\hline 23. I believe that art is important & 1 & 2 & 3 & 4 & 5 \\
\hline 24. I suspect others of hidden intentions & 1 & 2 & 3 & 4 & 5 \\
\hline 25. I pay attention to details & 1 & 2 & 3 & 4 & 5 \\
\hline 26. I rarely feel depressed & 1 & 2 & 3 & 4 & 5 \\
\hline 27. I am the life of the party & 1 & 2 & 3 & 4 & 5 \\
\hline 28. I don't like going to art galleries & 1 & 2 & 3 & 4 & 5 \\
\hline 29. I accept people as they are & 1 & 2 & 3 & 4 & 5 \\
\hline 30. It's hard for me to get down to business & 1 & 2 & 3 & 4 & 5 \\
\hline 31. I don't like myself & 1 & 2 & 3 & 4 & 5 \\
\hline 32. I would describe my experiences as rather monotonous & 1 & 2 & 3 & 4 & 5 \\
\hline 33. I like getting to know new ideas & 1 & 2 & 3 & 4 & 5 \\
\hline 34. I have a sharp tongue & 1 & 2 & 3 & 4 & 5 \\
\hline 35. I fulfill my daily duties without delay & 1 & 2 & 3 & 4 & 5 \\
\hline 36. I feel good about myself & 1 & 2 & 3 & 4 & 5 \\
\hline 37. I can deal with social situations & 1 & 2 & 3 & 4 & 5 \\
\hline 38. I am inclined to vote for conservative politicians & 1 & 2 & 3 & 4 & 5 \\
\hline 39. I respect other people & 1 & 2 & 3 & 4 & 5 \\
\hline 40. I forget about my responsibilities & 1 & 2 & 3 & 4 & 5 \\
\hline 41. I panic easily & 1 & 2 & 3 & 4 & 5 \\
\hline 42. I don't like getting attention & 1 & 2 & 3 & 4 & 5 \\
\hline 43. I take care of a high level of discussion & 1 & 2 & 3 & 4 & 5 \\
\hline 44. I often offend others & 1 & 2 & 3 & 4 & 5 \\
\hline 45. I am always prepared & 1 & 2 & 3 & 4 & 5 \\
\hline 46. I rarely get irritated & 1 & 2 & 3 & 4 & 5 \\
\hline 47. I know how to get people interested & 1 & 2 & 3 & 4 & 5 \\
\hline 48. I am not interested in abstract ideas & 1 & 2 & 3 & 4 & 5 \\
\hline 49. I have a good word for everyone & 1 & 2 & 3 & 4 & 5 \\
\hline 50. I'm wasting my time & 1 & 2 & 3 & 4 & 5 \\
\hline
\end{tabular}

Factors of personality traits and their related checklist item numbers:

Neuroticism: 1, 6, 11, 16, 21, 26, 31, 36, 41, 46

Extraversion: 2, 7, 12, 17, 22, 27, 32, 37, 42, 47

Agreeableness: 4, 9, 14, 19, 24, 29, 34, 39, 44, 49

Openness to experience: $3,8,13,18,23,28,33,38,43,48$

Conscientiousness: $5,10,15,20,25,30,35,40,45,50$

Source: Author's own work based on: Strus et al. (2014). 